\title{
Philippe Lejeune: An American(ist)'s Appreciation
}

\section{G. Thomas Couser}

I'm not sure just when I became aware of Philippe and his work. It must have been through John Eakin, who arranged for the translation of the pieces in On Autobiography. I suppose I first read that in the early 1990s-a long time ago!

Nor am I sure when I first met Philippe, probably in 1999. In advance of the 1999 IABA conference in Beijing, John Eakin arranged for a small group of friends and colleagues to tour in a mini-bus. The group included Philippe and his wife Violaine, whom John and Sybil had known for some time. Philippe's English is much better than my French, but I welcomed the opportunity to attempt some remarks in his language. He seemed to appreciate that. And I greatly enjoyed his company. He was an appreciative traveler in a land that was new to both of us.

The language barrier between us led to a memorable interaction years later. At the IABA conference in Sussex in 2010, Philippe generously attended a panel in which I gave a paper entitled "My Father's Early Life in Letters: Reflections of a Critic Turned Memoirist." In mid-paper, to my surprise and chagrin, I completely lost my composure while reading a love letter written to my father by a male friend. I sobbed loudly as the audience tried to avert its eyes. Afterwards, Philippe approached me and said that, although he could not follow my paper, he understood it was very moving. I found that touching and amusing, all at once.

Because of my interest in illness and disability narratives, some years later he sent me a copy of a diary by a young Frenchman who had died of cystic fibrosis. It had been published in France, and he hoped that I could arrange to have it translated and published in English. I was not able to do that, but I attempted to read it. My French might have been adequate, but the author, still in his teens and writing privately and informally, used slang that eluded me (and my dictionary). As far as I could tell, though, it 
was a charming narrative of a life with a fatal disability. I was pleased that Philippe had thought of me.

I was not particularly interested in diary writing at the time. But a few years ago, I was given access to the diary of a friend and colleague who'd kept one for decades, from his twenties on. Reading through it was a revelation: I came to know Charles in completely different ways than I had known him in person over the last decades of his life. Belatedly, then, I have begun to appreciate Philippe's work on diary writing, which he has now resourcefully extended from the page to the screen.

Of course, the work that is most identified with Philippe is probably his concept of the autobiographical pact. It has been critiqued and modified, not least by Philippe himself, but for me it remains a touchstone that reminds us that autobiography and memoir exist in a relationship with the world that is different from that of fiction. Granted, the borders are often not distinct-and may be crossed or blurred to good effect-but it remains important to remember that memoir works and matters in ways that distinguish it from fiction.

The Lejeune work that has been most useful and important to me, however, is "The Autobiography of Those Who Do Not Write." I drew heavily on it in Vulnerable Subjects, especially in chapter 3, "Making, Taking, and Faking Lives: Voice and Vulnerability in Collaborative Life Writing." (Indeed, in looking over that chapter again, I realize that, although I cited Philippe repeatedly, I probably did not acknowledge him as fully as he deserved.) In any case, nothing I have read (or written) on this complex topic compresses more wisdom and insight into as few words as his essay.

To begin with, Philippe distinguishes between two distinct scenarios. In one (which I term the celebrity scenario), the subject (or "model"), though famous or accomplished, requires the assistance of a ghostwriter to produce a marketable narrative of his life; in the other (which I call the ethnographic scenario), the subject is obscure, illiterate or pre-literate, and typically represents a demographic, racial, or ethnic category. The notions of authority and the power dynamics of collaboration differ accordingly in these two contrary scenarios.

By way of offering an appreciation of his essay here, let me gloss a few pithy quotations.

Of the first scenario, Philippe remarks,

By relatively isolating the roles [of author, narrator, and "model"], the collaborative autobiography calls into question again the belief in a unity that underlies the autobiographical genre, the notion of author and that of person. We can divide the work in this way only because it is in fact always divided in this way, even when the people who are writing fail to recognize 
this, because they assume the different roles themselves. Anyone who decides to write his life story acts as if he were his own ghostwriter. (188)

Interestingly, this counterintuitive observation serves to qualify or complicate his notion of the autobiographical pact, which depends on the "identity" of the author, narrator, and subject or protagonist:

Collaboration blurs in a disturbing way the question of responsibility, and even damages the notion of identity. The model and the writer both tend to believe that they are the principle, if not the only, "author" of the text.... And it is true that the "life" in question belongs to both of them-but perhaps also, for the same reason, belongs neither to one nor to the other. (192)

Therein lies the potential for conflict between the collaborators-over the "final edit," over title-page credit, and of course, over any monetary proceeds. Collaboration calls into question the very notion of ownership: whose life is it, anyway?

Philippe is equally shrewd about the obverse scenario, which involves a subject who requires a collaborator because s/he "does not write." Here he is particularly interested in the problem of writing the lives of "common" people (who do not write but live in a literate society) rather than the lives of preliterate people (the typical subjects of ethnography, who do not know how to write):

Their story takes its value, in the eyes of the reader, from the fact that they belong (that they are perceived as belonging), to a culture other than his own, a culture defined by the exclusion of writing. (196, emphasis original)

He then unpacks the ironies inherent in this endeavor:

All merit in his story is a merit added by the writing, or rather by the new network of communication into which the mediatory introduces him: the unhappy person would understand it if he then takes it into his head to write himself. His credit would collapse. He is in fact the creature of his ethnographer.

The signature system of a book changes therefore according to whether the model is hero or antihero, according to whether he belongs or does not belong, on a symbolic level, to the world of writing. (196, emphasis added)

Further,

The common desire, present as much in scientific investigations as in bookstore publication, is to see, and to make seen, what is hidden from sight, to grasp what cannot be grasped, to constitute as the object of knowledge a 
kind of absolute other. This hidden treasure is defined negatively: it is what is on the other side of writing. ... In a way, what we try to capture exists only in the potential state and could never take the form of speech without the intervention of the investigator. (207)

This doomed endeavor creates what Lejeune terms "the ethnological gap."

If we use the speech of the model, it is less to give it to him than to take it from him. There is the ambiguity of any ethnological attempt: the act that fixes and preserves the memory of an "oral" society, at the same time alienates it, recovers it, and reifies it. ... And if, as happens sometimes, the investigation arouses in him an autobiographical vocation, and if he buys a notebook to write his own life story, the investigator will have the feeling of being in his turn short-circuited, and will be irritated or moved by this effort of the model to take his life in hand again. (209)

This analysis is all the more impressive for being embedded in, and seeming to grow out of, a running account of centuries of Francophone texts. Philippe's examples and illustrations were not familiar to me, but they manifest the solid grounding of his concepts in traditional French life writing.

As an Americanist, I find this piece appealing because of how it illuminates genres like the slave narrative (when its composition is collaborative). It took scholars a long time to acknowledge the complex dynamics of slave narrative; indeed, I'm not sure that scholarship has fully recognized the extent to which the experience of slavery remains beyond representation by those who have escaped it and are able to narrate it, with or without help. Philippe's critique also pertains to the problematic status of "working-class autobiography."

If there's a canon of American autobiography, it certainly must include Black Elk Speaks, which richly illustrates the complexity of cross-cultural ethnographic collaboration. In Altered Egos, I argued that to a significant degree "Black Elk's" narrative reflects the agenda of his Caucasian collaborator, John Neihardt, despite the latter's claim that the Lakota elder spoke "through" rather than to, or with, him. (In fact, the collaboration involved several supplementary parties: Black Elk's son, some other Lakota elders, and Neihardt's daughter.)

As it happened, Black Elk later took it upon himself to issue a kind of sequel to Neihardt's narrative, which had conveniently neglected to indicate in any way that, after the Massacre at Wounded Knee, Black Elk had converted to Roman Catholicism and functioned as a catechist on the reservation. In Black Elk Speaks again Black Elk corrected this omission, thus 
calling into question the authority of the earlier narrative. Predictably, this text did not have the currency and circulation of Neihardt's book. It took scholars decades to discover it and reckon with its implications. (Of course, its authority is also questionable: it may have been issued at the request of the Catholic missionaries whose work Black Elk advanced and who were taken aback by Neihardt's depiction of him as an unreconstructed Lakota.)

For these reasons and more, any life-writing scholar unfamiliar with this essay should read it; those familiar with it will find it rewards re-reading. If Philippe had published nothing else, his work on the pact and on collaborative autobiography would earn him a place in the pantheon of life-writing critics.

Another noteworthy aspect of Philippe's work is exemplified in his work on the autobiography of those who do not write: although it is manifestly "informed by" post-structural theory and is loosely deconstructive in its approach, it is devoid of abstruse theoretical terminology. It illustrates that it is possible to read and write in a way that is theoretically sophisticated without recourse to excessive abstraction. Rather than flaunt his familiarity with high theory, Philippe just puts it to work to illuminate and complicate some common life-writing transactions.

A final feature of Philippe's work may also be overlooked-because after all, scholarship is serious business-his dry humor. I don't have enough sense of French scholarship to know how typical it is to be funny, and if so, how Gallic his humor is. All I know is that it seems to come across well in translation and that I thoroughly enjoy it. (I find some of it in the observations quoted earlier.) Those familiar with his sly smile will make the connection between his self-presentation on the page and in person.

Vive Lejeune!

\section{WORKS CITED}

Couser, G. Thomas. Altered Egos: Authority in American Autobiography. New York: Oxford UP, 1989. Print.

Couser, G. Thomas. Vulnerable Subjects: Ethics and Life Writing. Ithaca: Cornell UP, 2004.

Lejeune, Philippe. On Autobiography. Ed. Paul John Eakin. Trans. Katherine Leary. Minneapolis: U of Minnesota, 1989. Print.

Neihardt, John G. Black Elk Speaks, Being the Life Story of a Holy Man of the Oglala Sioux. New York: Morrow, 1932. Print. 


\section{ABOUT THE AUTHOR}

G. Thomas Couser is Professor of English emeritus at Hofstra University in New York and founding director of the Disability Studies Program. Among his books are Recovering Bodies: Illness, Disability, and Life Writing (Madison: University of Wisconsin Press, 1997), Vulnerable Subjects: Ethics and Life Writing (Ithaca: Cornell University Press, 2004), Signifying Bodies: Disability in Contemporary Life Writing (Ann Arbor: University of Michigan Press, 2009), and Memoir: An Introduction (New York: Oxford University Press, 2012). His most recent book is Letter to My Father: A Memoir (Hamilton Books, 2017). 